\title{
Class, Consensus and Repertoire at the Nottingham and Midland Counties Working Classes Industrial Exhibition. ${ }^{1}$
}

On March $16^{\text {th }} 1865$, during one in a series of meetings held to determine the structure and scope of the forthcoming Nottingham and Midland Counties Industrial Exhibition, a member of the Nottingham Town Council outlined both the financial infrastructure and the aims underpinning the forthcoming event. ${ }^{2}$ Councillor Bradshaw:

[...] expressed his gratification that the gentlemen in the town and neighbourhood had come forward so well as guarantors, something like $£ 1,300$ having been guaranteed up to the present time [...] and concluded by moving the following resolution: “That [the] Working Classes' Industrial Exhibition being calculated to encourage arts, science, and mechanics, and improve the taste generally of the working classes, this meeting pledges itself to co-operate with the promoters of the Nottingham and Midland Counties Industrial Exhibition, with a view to ensure its success."

In such press reports, as in the title for the event, the productivity of working class men was placed at the heart of the enterprise, whilst revealing just how 'calculated' the actual contribution from that section of the community would be: it was affluent 'gentlemen' guarantors in and around Nottingham that determined the structure and content of the Exhibition. Indeed, by May 1865 the Nottingham and Midland Counties Daily Express acknowledged the lack of agency afforded to those contributing artefacts to the event, noting that ' $[e]$ xhibitors must belong to the "working class;" but as that phrase is somewhat ambiguous in its simple form, the committee will

\footnotetext{
1 Research for this article has been undertaken as Postdoctoral Research Fellow for the project 'Mapping Performance Culture: Nottingham 18571867', funded by the Arts and Humanities Research Council (AHRC), and undertaken at the University of Nottingham, with Dr Jo Robinson from the School of English Studies and Dr Gary Priestnall from the School of Geography as co-investigators. Other members of the project team were Dr Robin Burgess (Geography) and Dr Richard Tyler-Jones (Information Services), and we have been aided considerably by Nottingham City Libraries and Museums and the Nottinghamshire County Archive. Each year the AHRC provides funding from the Government to support research and postgraduate study in the arts and humanities, from archaeology and English literature to design and dance. Only applications of the highest quality and excellence are funded and the range of research supported by this investment of public funds not only provides social and cultural benefits but also contributes to the economic success of the UK. For further information on the AHRC, please see www.ahrc.ac.uk <http://www.ahrc.ac.uk>.

2 City status was only conferred at the end of the nineteenth century, in Queen Victoria's Jubilee year of 1897., but during the period under discussion the size of Nottingham and its population both increased substantially. Its population rose from 53,091 in 1841 to 239,745 in 1901; its size increased from 876 acres at the beginning of the century to over 10,000 acres as it expanded first through the Enclosure Act of 1845 and then in 1877 by drawing in the neighbouring satellites of Sneinton, Basford, Bulwell, Radford and Lenton.

${ }^{3}$ Nottingham Journal, 17 March 1865, p. 2.
} 
be empowered to judge as to whom it includes. ${ }^{4}$ Rather than foregrounding the achievements of working class citizens engaged in the field of industrial development, therefore, the Exhibition was primarily concerned with the depiction of working class residents of Nottingham and surrounding towns as amenable, industrious and essentially passive. Press reports played a fundamental role in constructing that depiction, indicating a drive for social cohesion in midVictorian Nottingham; for example the following report, from the Nottingham Journal:

It is known probably that a labourer named Thomas Crofts, at Sutton-on-Trent, brought a model of a church to the exhibition. In addition to making the model, which is a marvel of perseverance and skill, we are informed that he brought it from Sutton in a wheelbarrow! His case has attracted some sympathy and we are glad to learn that some of the men in Bottom's factory have subscribed 16s. 11d. For him, as an encouragement to his industry. ${ }^{5}$

This excerpt represents the work of one exhibitor and support from his professional community, yet the activity cited in this item cannot be considered representative of all working class residents. Rather, it seeks to promote individual enterprise as representative of ideal behaviour within that class. Crofts becomes an emblem, 'a marvel of perseverance and skill' financed by factory workers who, by their fiscal contributions, uphold such enterprise. By comparison, in the decade 1851 to 1861 the number of female labourers in the town grew by more than 7,000 , but any contribution by this section of the working class to the Exhibition was not advertised. ${ }^{6}$ Charting the way in which the event is reported, it becomes apparent that the fraternal network promoting the project determined a restrictive, rather than an inclusive arena for participation. Peter Bailey notes that, by the mid nineteenth-century, demarcating such respectable enterprise provided the opportunity to 'incorporate a minor but significant section of the working class into the social consensus that assured mid-Victorian society in particular its overall cohesion and stability'. ${ }^{7}$ Bailey is examining the relationship between concepts of respectability and social cohesion, and clearly, the extent to which such proscribed inclusiveness succeeded in

\footnotetext{
${ }^{4}$ Nottingham and Midland Counties Daily Express 23 May 1865, p. 4.

5 Nottingham Journal, $16^{\text {th }}$ September 1865 , p. 2. The Journal was a newspaper with Tory sympathies but nevertheless showed through such reports support for an Exhibition developed by local councillors and a town council characterised, in the mid nineteenth-century, by a Liberal-Whig majority, indicating a social rather than political consensus in the organisation of the Exhibition.

${ }^{6}$ Roy Church has calculated from planning reports and census records that more than 120 factories were erected in Nottingham during the 1850s, and female labour grew by more than 7,000 as workers came to Nottingham from surrounding counties. Economic and Social Change in a Midland Town (London: Frank Cass, 1966), pp. 228, 234

7 Peter Bailey, Popular Culture and Performance in the Victorian City (Cambridge: Cambridge University Press, 1998), p. 30.
} 
promoting 'social consensus' must be interrogated. This article will further scrutinise the Nottingham and Midland Counties Working Classes Industrial Exhibition as an attempt to manifest such consensus in a town that had experience social unrest related to industrial expansion, economic depression and political radicalism earlier in the century.

\section{An exhibition for Nottingham.}

The practice of mounting temporary exhibitions to display industrial and cultural achievement was popularised, initially, by the Great Exhibition of the Works of Industry of All Nations, held in London from May to October 1851. Writing of the manner in which issues surrounding class became integral to the 1851 event, Peter Gurney notes:

The significance of the Great Exhibition as a turning point in class relations is a major component part of the dominant historical representation of the event. From the outset the Great Exhibition was made to symbolise the triumph of laissez-faire capitalism and British industrial hegemony certainly, but the good behavior of the working-class crowd on shilling days was also frequently remarked upon in the bourgeois press. $^{8}$

The Exhibition was presented as a forum within which to prescribe and display an ideal representation of class and subsequent, similar events took place on a smaller scale in regional, and notably industrial centres throughout the United Kingdom; indeed the South London and Birmingham Industrial Exhibitions also took place in 1865 and in that same year Crystal Palace, still open although transplanted to Sydenham, was displaying items made by working-class craftsmen. Exhibitions produced a framed version of order at a time of profound social and industrial development, responding to such development by the classification of material goods, and the framing of behavior in designated spaces. In the case of Nottingham, throughout the 1850 s and 1860s, regular periods of economic depression resulted in large groups of unemployed labourers resident in and around the town, and certainly by the final months of 1864, after trade with America had been severely disrupted by civil war, unemployment among labourers was high, as indicated by increased applications to the workhouse. ${ }^{9}$ Therefore, a drive

\footnotetext{
${ }^{8}$ Peter Gurney, 'An appropriated space: the Great Exhibition, the Crystal Palace and the working class' in The Great Exhibition of 1851: New interdisciplinary essays edited by Louise Purbrick (MUP: Manchester, 2001), 114-145, pp. 115-6.

9 Workhouse inmates increased from 742 on November $25^{\text {th }}$ to 814 on December $16^{\text {th }}$. Statistics taken from the Nottingham Review 16 December 1864, p. 7.
} 
at that time to represent working class residents as productive in and beyond the workplace, becomes increasingly understandable.

However, as has been indicated, the role of participants from that section of the community was not foregrounded in reports of preparations for the event. At the laying of the foundation stone on March $22^{\text {nd }} 1865$ a procession, starting from the seat of the Town Council, the Exchange Hall, was populated by civic leaders:

Shortly before twelve o'clock a large body of gentlemen had assembled in the Mayor's parlour, where wine and biscuits had been provided. After a short interval the procession started from the Police-office doors in the following order: Banners and flag bearers, band of the Robin Hood Rifles under the direction of Mr. Turpin, the contractors, the committee of management, the general committee [...] members of the corporation, auxiliary committees, the Mayor of Nottingham (Alderman Page), Mayor of Lincoln (Mr. R. Sutton Harvey), Mayor of Stamford (Mr. John Groves), the Town Clerk, the County Coroner and other officials, and the borough police band under the direction of Mr. Carter [...] The Mayors of Nottingham and Stamford wore their robes, giving the procession a rather more striking appearance than it would otherwise have had. ${ }^{10}$

Moving north from the Market Place, where the office of the Mayor was situated, towards the site of the Exhibition hall, a collective including local and regional officials and the band of the volunteer militia alerted an audience witnessing the procession to the presence of a new site that would represent industrial and cultural achievement associated with the town. Absent from the procession and relegated to the role of passive audience members were working class residents of Nottingham.

The site used for the Exhibition further subsumed the role of working class citizens. The hall was erected in an area to the north of the town centre that was characterised by legitimate cultural activity: by March 1865, a School of Art and new Theatre Royal were also under construction in that vicinity, distinguishing a cultural sphere that was set apart from, for example, the increasingly industrial area to the East of the Market Place, where the original Theatre Royal was located. ${ }^{11}$ This developing section of Nottingham, a product of collaboration between civic authorities and private investors (including the 'gentlemen' guarantors for the Exhibition), further

\footnotetext{
${ }^{10}$ Nottingham Journal 23 May 1865, p. 4.

11 When the new Theatre Royal was built to the north of the Market Place and opened in September 1865, the original Theatre Royal building at St. Mary's Gate was re-opened as the Alhambra Music Hall.
} 
subsumed the actual, individual contributions of working class residents to one, particular event. Ceremony accompanying the opening of the Exhibition on September $12^{\text {th }} 1865$ further emphasised this, as an expanded version of the collective present at the laying of the foundation stone moved through the centre of the town and further imprinted the significance of the location of this Exhibition upon spectators. Reproducing the structure of the procession provides some indication of scale, and Figure 1 represents the large body of civic leaders who asserted the prominence of the Exhibition within Nottingham:

$[\text { Fig } 1 \text { here }]^{12}$

Figure 1: 1 Participants in the opening ceremony for the Nottingham and Midland Counties Working Classes Industrial Exhibition, and their place in the procession.

This collective not only advertised the opening of the event, but defined an area of Nottingham within which diverse audiences could engage in shared, rational entertainments selected and administered by civic authorities, framing working class contributions to the Exhibition as one aspect of a wider drive for social cohesion. Charting the route taken on a map of the mid nineteenth-century town, it is possible to further consider the influence of this kind of spectacle within the urban landscape:

[Fig 2 here ${ }^{13}$

Figure2: Route of the procession to mark the opening of the Nottingham and Midland Counties Working Classes Industrial Exhibition, September 121865

The lengthy, indirect route taken emphasises how the procession was extended to advertise the forthcoming Exhibition to a large number of spectators who were sharing space with the participants. This was a marketing strategy usually associated with travelling, overtly commercial entertainments, such as circuses, that would process through the streets to advertise their presence in the town but here, the procession demarcated an area to the north of the Market Place where legitimate recreation was available. The particular area defined by this route distinguished the space in which the Exhibition was to be mounted from sites associated with social unrest, such as the Market Place itself and the Castle to the south; for example as recently as June 1865 riots had broken out in the Market Place over the platforms given to candidates within the town centre for election campaigning. ${ }^{14}$ The spectator for this part of the

\footnotetext{
12 Reproduced from a report provided in the Nottingham Journal, 12 September 1865, p. 2.

13 Digital map of Nottingham, Mapping the Moment website (www.nottingham.ac.uk/mapmoment). Original map image courtesy of Nottingham City Libraries, Local Studies Library. The parade route recorded on the website has been developed from information provided in local press reports for the event.

14 The burning of Nottingham Castle on $9^{\text {th }}$ October 1831 by protesters campaigning over Reform is perhaps the most notable example of such political unrest in Nottingham during the nineteenth century.
} 
opening ceremony witnessed both the promotion of an individual Exhibition and a changing urban landscape, characterised by stable civic authority.

The exclusivity associated with these processions meant that it was not until general admission to the hall began on the evening of September $12^{\text {th }}$ that a working class presence amongst visitors, as well as exhibitors, was initiated. Admission to the Exhibition was 6d., a competitive price paralleling entrance to a concurrent exhibition at the School of Art, and also the cheapest seats for local music halls. ${ }^{15}$ Attendance figures for the Exhibition, up to the end of 1865, attest to a large, diverse, and returning audience, indicating that a modest admission price, available occasionally at the Great Exhibition of 1851, but a sustained policy for this event, encouraged attendance:

\begin{tabular}{|ll|}
\hline Week Ending & Attendance \\
\hline September $19^{\text {th }}$ & 4,370 \\
September $26^{\text {th }}$ & 5,182 \\
October $3^{\text {rd }}$ & 14,931 \\
October $10^{\text {th }}$ & 21,118 \\
October $17^{\text {th }}$ & 4,564 \\
October $24^{\text {th }}$ & 4,725 \\
October $31^{\text {st }}$ & 3,947 \\
November $7^{\text {th }}$ & 4,517 \\
November $14^{\text {th }}$ & 5,161 \\
November $21^{\text {st }}$ & 6,800 \\
November $28^{\text {th }}$ & 4,523 \\
December $5^{\text {th }}$ & 5,220 \\
December $12^{\text {th }}$ & 5,313 \\
December $19^{\text {th }}$ & 5,472 \\
December $26^{\text {th }}$ & 9,516 \\
January $2^{\text {nd }}$ & $9,520^{16}$ \\
\hline
\end{tabular}

Figure 3: Attendance figures for the Nottingham and Midland Counties Industrial Exhibition to the end of 1865

\footnotetext{
15 Entrance to the School of Art Exhibition of 1865 was 6d., the Alhambra Music Hall, charged 6d. for floor or side box tickets (rising to $1 \mathrm{~s}$. for the stalls).

16 Statistics were published on a weekly basis in the Nottingham Journal until January 1866; this run of figures is taken from Nottingham Journal, January $4^{\text {th }} 1866$, p. 2.
} 
The exceptional number for the first weeks in October and for late December show how visitors to a renowned annual event within Nottingham, Goose Fair, also attended the Exhibition, and that a large holiday audience was present over the Christmas period. The event drew visitors from beyond Nottingham, who took advantage of a developing transport infrastructure (with two stations serving Nottingham by this date) that was sustaining new cultural as well as manufacturing industries.

\section{Repertoire at the Exhibition.}

What was presented to visitors within the hall at Nottingham is represented by an image published in the Illustrated London News [Fig. 4]; this shows the manner in which industrial items were distinguished by the site of manufacture and the hall replicated, on a smaller scale, the layout found at Crystal Palace in 1851. What this image also depicts, is the manner in which cultural artefacts and a dedicated space for staged entertainments were integral to the event:

[Fig 4 here] ${ }^{17}$

Figure 4: the Exhibition hall, as depicted in the Illustrated London News, (c) Illustrated London News Ltd/Mary Evans.

The hall was 220 feet long and 68 feet wide, with industrial machinery compartmentalised by location on the ground floor, and local artwork on an upper balcony. At the Eastern end of the hall, and not depicted in the picture, was machinery in motion and steam powered apparatus (most having some relationship with the lace trade). In the centre of the ground floor were smaller items used in the textile industry, as well as displays of carved objects, and some images taken by local amateur photographers. Paintings were hung around the balcony. What is placed at the centre of this image, though, is the organ installed at the Western end of the hall; this was an integral component of the Exhibition, used regularly during the musical performances staged daily at the venue.

The juxtaposition of static objects and dynamic performers was by no means exceptional; the Great Exhibition included spectacular artworks and posed reconstructions that added an element of actual performance, making the event, in the name of one visitor, an 'animated cosmorama'. ${ }^{18}$ Commenting upon the essential variety that made the 1851 Exhibition

\footnotetext{
17 Illustrated London News, October 71865 p. 332.

18 John Cole writing in 1859, quoted in Jim Davis and Victor Emeljanow, Reflecting the Audience: London Theatregoing, 1840-1880 (Hatfield: University of Hertfordshire Press, 2001), p. 172.
} 
so popular (in the sense of appealing to a cross-class audience), Jim Davis and Victor Emeljanow have noted the "variety of its inclusion - both competitive and yet complementary and the opportunities for making money by juxtaposing rational amusement with visceral satisfaction." ${ }^{19}$ At Nottingham, in 1865, it is apparent that the combination of objects and live performance provided a similar, stimulating experience for visitors, and careful preparation for the Exhibition indicates that a musical repertoire was planned as integral to the event. Before the space opened, the acoustics were tested, on August $31^{\text {st }} 1865$ :

The capabilities of the hall for music was tested last night. The following glees were sung by the choir of the Blind Asylum, under the able management of Mr. Coburn: "Dawn of Day," "Blue Bells of Scotland," "Behold the Woods," "Awake Æolian Lyre," and the following played by the sax tuba band, under the leadership of Mr. W. Norman: "William Tell," "De Juno Quadrille," "Butterfly's Ball Polka," and "Quick March." The result was most satisfactory - there being no unpleasant reverberation; and indeed the absence of deep embrasures and interruptions to the wave of sound seems to promise for the more delicate delights of the less noisy music a singularly excellent arena. $^{20}$

Musical performance and, towards the end of the Exhibition some comic entertainments were mounted within the hall, a varied programme developed to sustain the attraction. Of significance here is a conflict between stated social and actual fiscal aims, as the repertoire altered, initially foregrounding social consensus through cross class amateur contributions, then changing to a program emphasising professional contributions, aimed at a large and returning audience.

During September and the first half of October, repertoire was characterised by local, amateur performers. Noting that in the first weeks the hall became most crowded in the evening, out of working hours, the Nottingham Journal considered the role of musical entertainment in encouraging attendance:

In the forenoon the attendance of visitors has so far been remarkably small; in the afternoon, the numbers are probably trebled or quadrupled, but it is only in the evening when there is anything like a full attendance, and then it is that the working classes flock to see what Lord Belper called their own exhibition. It is very interesting to see the visitors crowd round the ribbon-weaving loom from Leicester

\footnotetext{
19 Davis and Emeljanow, p. 172.

${ }^{20}$ Nottingham Journal, September 2 1865, p. 2.
} 
- how they watch the mysterious turnings of the jacquard-cards aloft, the intricate intermingling of the threads, the strong precision of the shuttles with their different coloured silks, and the results produced [...] The great organ, on every trial, appears to better advantage, and the performances upon it in the evening by Mr. Turpin are a source of great enjoyment to those who are musically endowed. ${ }^{21}$

The distinction between popular interest in the machinery and a more precise interest in the musical entertainment provided suggests that each aspect of the Exhibition could draw its own visitors. The musical repertoire was, of course, the most versatile attraction and the staging of concerts that might be enjoyed by those attending at the end of each day shows an awareness that variety was required to encourage a returning audience. Following one week of concerts on the organ by Turpin, performers on September $19^{\text {th }}$ were an anonymous 'Lady' pianist in the afternoon, and local music teachers, the Misses Campbell, with a sung entertainment in the evening. ${ }^{22}$ This concert was followed on consecutive days by the Christian Sax Tuba band, and a pupil of Turpin's, continuing a repertoire of local, amateur musicians. That this pattern was sustained throughout the first part of October signals an aim to characterise the venue as a site where local artists performed, with both Turpin and the Misses Campbell returning during Goose Fair week. However, at this point the performance repertoire becomes characterised by marketing strategies aimed at maximizing profit, that ultimately displaced local, amateur performers.

There was a move to combined amateur and professional programmes, and on occasional evenings to the appearance of professional performers alone; this was a repertoire that adapted and developed over time to further encourage the widest possible audience that would attend the Exhibition from areas in and beyond Nottingham. At a concert on October $18^{\text {th }}$, a vocalist from the Halle in Manchester appeared, and two days later, there was a 'grand miscellaneous concert' staged by local musician M. Jullien, featuring both amateur and professional musicians. ${ }^{23}$ The repertoire increasingly resembled programmes at existing venues within the town; for example, the Mechanics' Hall staged large concerts under the direction of amateur musicians, as well as the work of professional, touring artists. This alteration in repertoire allowed for a development of the pricing structure for the Exhibition; as the event drew to a close in January 1866, it was determined that a loss would be incurred, and an

\footnotetext{
21 Nottingham Journal, 19 September 1865, p. 2.

22 The anonymous performer was simply referred to as a 'Lady' in an ad for musical entertainment in the Nottingham Journal 19 September 1865, p. 2.

${ }^{23}$ This concert was under the director of local musician M. Jullien; programme reproduced in the Nottingham Journal 19 October 1865, p. 2.
} 
additional 3d. was charged for some entertainments during that month. The presence of artists from a national, professional arena as well as a local, largely amateur circuit was intrinsically linked to the drive for profit. For example, on $27^{\text {th }}$ January renowned local musician John Farmer mounted a concert 'in aid of the Exhibition Prize Fund'. ${ }^{24}$ Farmer and his brother Henry were well known performers in the town, and produced events featuring professional musicians; indeed, John Farmer mounted an annual concert at the Mechanics' featuring both amateur and professional artists. Therefore, the Exhibition repertoire consistently reflected the prominence and popularity of musical entertainment within Nottingham, but as the event progressed, it also came to represent the hall as an exclusive concert venue on particular evenings. By the first months of 1866, the competitive pricing and prominence of local artists had both been undermined in a drive for profit.

This developing repertoire, that both featured and yet constrained the individual, local performer, effectively mirrored the treatment of working class exhibitors who, rather than being afforded a platform to display personal accomplishments, had selected items framed to depict a particular and a limited version of that class and the wider community without allowing individual citizens any control over the structure and content of the ongoing Exhibition. Both a drive for profit and concern regarding social cohesion had fundamentally influenced the event. However, crucially, the presence of a diverse visiting public presented a challenge to this prescriptive influence. For example the Nottingham and Midland Counties Daily Express noted the disruptive presence of some spectators for a performance by Mr. and Mrs. Foster:

Last evening these versatile artistes gave their first entertainment at the exhibition, and the building was much more crowded than we have seen it for some time past. All the seats were fully occupied, and every portion of standing room near the platform was taken up [...] The only drawback was the noise created by some young people in the gallery, who, being unable to secure good places, were restlessly wandering above during the whole of the evening. ${ }^{25}$

Such accounts mark how the local press, initially dedicated to positive advertisement of a forthcoming event, came to reflect the actual 'social consensus' - returning to Bailey's words that was achieved. ${ }^{26}$ The social cohesion that organisers of this Exhibition endeavoured to promote is disrupted by the presence of the individual, social and economic background

\footnotetext{
${ }^{24}$ Nottingham and Midland Counties Daily Express 29 January 1866, p. 3.

25 Nottingham and Midland Counties Daily Express 2 February 1866, p. 2.

26 Peter Bailey, p. 30.
} 
unknown, who is able to experience the exhibits and the entertainments on their own terms. The 'marvel' of working class industry represented by Thomas Crofts, producer of a single exhibit, the choreographed version of civic authority portrayed during opening ceremonies, and the version of Nottingham performance culture promoted by a co-ordinated musical repertoire, were not complemented by a passive and compliant Exhibition audience. ${ }^{27}$ The active, vocal spectator is not, perhaps, a surprising outcome in a venue that did not separate the performance and display areas, but the control over environment exercised by these audience members emphasises discrepancies between the aims and outcomes of this Exhibition, as the actual behaviour of individual visitors opposed efforts to use the event to represent civic authority and cross-class consensus.

Indeed, events throughout the closing day indicate the acknowledgement, by civic leaders, that another formal ceremony could not subsume the realities of a complex social arena. When the Exhibition closed on February $10^{\text {th }} 1866$, the Nottingham and Midland Counties Daily Express reproduced in summary a closing speech by Chair of the Exhibition Committee, Councillor Harrison, where he argued that 'as their former ceremonials - at the laying of the first stone, and at the opening of the Exhibition - had proved a severe pecuniary loss to the Committee, they would see the propriety of not going through any formal ceremony this evening. ${ }^{28}$ In mounting this Exhibition, authorities could advertise a developing urban environment in which rational entertainments advertised a Nottingham free from social, political and economic upheaval, yet losses incurred by the event, like the presence of the independent spectator within the Exhibition hall, portrayed a rupture between ideal and actual material conditions. Both factors revealed that the drive for 'social consensus', along class lines, was futile. ${ }^{29}$

\footnotetext{
${ }^{27}$ Nottingham Journal, $16^{\text {th }}$ September 1865, p. 2.

${ }_{28}$ Nottingham and Midland Counties Daily Express 12 February 1866, p. 2.

${ }^{29}$ Peter Bailey, p. 30.
} 